Cahiers $d u$ MONDE RUSSE

\section{Cahiers du monde russe}

Russie - Empire russe - Union soviétique et États indépendants

$58 / 1-2 \mid 2017$

\title{
The Russian Revolution as Continuum and Context and Yes,-as Revolution
}

Reflections on Recent Anglophone Scholarship of the Russian Revolution

La révolution russe, continuum et contexte, certes, mais révolution aussi :

réflexions sur les recherches anglophones récentes sur la révolution russe

\section{Peter Holquist}

\section{OpenEdition}

Journals

\section{Electronic version}

URL: http://journals.openedition.org/monderusse/10068

DOI: 10.4000/monderusse. 10068

ISSN: $1777-5388$

Publisher

Éditions de l'EHESS

\section{Printed version}

Date of publication: 1 January 2017

Number of pages: 79-94

ISBN: 978-2-7132-2696-0

ISSN: $1252-6576$

\section{Electronic reference}

Peter Holquist, «The Russian Revolution as Continuum and Context and Yes,-as Revolution », Cahiers du monde russe [Online], 58/1-2 | 2017, Online since 01 January 2019, connection on 21 December 2020. URL : http://journals.openedition.org/monderusse/10068 ; DOI : https://doi.org/10.4000/ monderusse. 10068 


\section{THE RUSSIAN REVOLUTION AS CONTINUUM AND CONTEXT AND YES,-AS REVOLUTION}

\section{Reflections on Recent Anglophone Scholarship of the Russian Revolution}

There has been an important shift in the last two decades in how Anglophone literature has presented the Russian Revolution. A recent literature has placed the Revolution within a broader chronology (a continuum of war and revolution) and within a broader context (empire). For many years, the Revolution - in no small part due to an attempt to wrestle with the Soviet state's presentation of it-debated it in terms of its legitimacy and turning points. The fundamental work in English was William Henry Chamberlin's two-volume The Russian Revolution, 1917-1921. A very fine overview of the dynamics of the revolutionary process, it is also notable for defining the Revolution as an event that extended through the Civil War to the Bolshevik triumph (his second volume, on 1918-1921). ${ }^{1}$

In these debates over the perceived legitimacy of Revolution - coup or zakonomernost'? - a key question was whether imperial Russia on the eve of war faced prospects of development toward a constitutional order (a position championed by Michael Karpovich), versus a Soviet orthodoxy insisting on the inevitability of Revolution. Into this debate Leopold Haimson intervened in a two-part article published a few years before the fiftieth-anniversary centenary of the Russian Revolution. While treated now as the most doctrinaire presentation of the "pessimist" thesis (that is, that Imperial Russia was fated for Revolution even without

1. William Henry Chamberlin, The Russian Revolution, 1917-1921, 2 vols. (New York: MacMillan and Co., 1935). 
the war), the two-part article itself was the product of a series of exchanges and debates with a set of Soviet scholars in the preceding years. ${ }^{2}$

These debates were followed by a second generation of scholarship. In her lucid and sharply drawn analysis, Sheila Fitzpatrick argued for the social origins of the Russian Revolution. What was notable about this work was Fitzpatrick's chronology for the Revolution. While she dated its beginning conventionally in 1917 (there is a brief introductory chapter on the "setting"), her book extended the revolution out to 1932 (in its first edition) and to 1938 (in its second edition). ${ }^{3}$ Against this, Richard Pipes had argued-like Chamberlin, in a synthetic two-volume work, with one volume devoted to Revolution and the second to Civil War - that it was not social factors, but rather the perfidious actions of the Bolsheviks which accounted for the course of the Russian Revolution. ${ }^{4}$

As my article "Violent Russia" argued, the treatment of the Russian Revolution often took the form of a debate between a "theory of circumstance" - meaning Russia's backwardness 5 - and a "theory of ideology": 6

The theory of "circumstances" in the Russian case presents Russia's revolutionary violence as a feature specific to Russia. This interpretation argues for a Russian Sonderweg, in which the Russian past and Russian backwardness made Russian society particularly prone to convulsions of violence. [...] The school of ideology posits much different reasons for Russian revolutionary violence. Rather than features distinct to Russia or its revolutionary conjuncture of 1905-21, proponents of the ideological approach point either to the culture of the Russian revolutionary movement in general or Marxism as ideology in particular as the font for the violence in the revolutionary period.?

In that article, I sought to move beyond this binary and provide a specific geographic and chronological frame for the Russian Revolution.

2. See "From the Editors: An Interview with Leopold Haimson," Kritika: Explorations in Russian and Eurasian History, 8, 1 (Winter 2007): 1-12, here at 6-8. Haimson noted in that interview that he regretted the excessive emphasis on labor unrest in the prewar crisis, to the exclusion of additional social and political crises.

3. Sheila Fitzpatrick, The Russian Revolution, 1917-1932 (New York: Oxford University Press, 1982); Sheila Fitzpatrick, The Russian Revolution, second edition (New York: OPUS, 1994).

4. Richard Pipes, The Russian Revolution (New York: Vintage Press, 1990); Richard Pipes, Russia under the Bolshevik Regime (New York: Vintage Press, 1994).

5. Pipes, Russian Revolution and Russia under the Bolshevik Regime; Vladimir Buldakov, Krasnaia smuta: Priroda i posledstviia revoliutsionnogo nasiliia [The Red Time of Troubles: The Nature and Consequences of Revolutionary Violence] (M.: ROSSPEN, 1997); Orlando Figes, A People's Tragedy: The Russian Revolution, 1891-1924 (New York: Penguin Books, 1998).

6. For discussions of the role of Marxism, see Stéphane Courteois, et al., eds., The Black Book of Communism: Crimes, Terror, Repression (Cambridge: Harvard University Press, 1999), esp. xviii, 262, 727, 735, 739, and Martin Malia, The Soviet Tragedy (New York: The Free Press, 1994).

7. Peter Holquist, "Violent Russia, Deadly Marxism: Russia in the Epoch of Violence," Kritika: Explorations in Russian and Eurasian History, 4, 3 (Summer 2003): 627-652, here at 628-629. 
Russia's historical heritage did matter. But this historical heritage played out not as a set of eternal conditions, but as a set of factors within a specific time and space. The specific chronological conjuncture was the period from 1905 to 1921. In this period Russia's specific post-1905 domestic convulsions catalytically intersected with the overall European crisis of 1914-24. This "Europe" had its own historical specificity. Russia's own "Time of Troubles" unfolded within the eastern European shatter zone of dynastic land empires, at precisely the moment that these societies were imploding during World War I. Thus, rather than treating Russia's 1917 experience in isolation, both chronologically and geographically, I propose situating 1917 instead both as a fulcrum in Russia's 1905-21 "Time of Troubles" and within the overall European convulsion from 1914 to 1924.8

Since that article, a new literature has provided new ways of looking at the Revolution. In particular, recent studies have used two lenses for analyzing the Revolution: War and Empire. And as regards situating the Russian Revolution within the First World War, there are two common vectors: continuum (that is, viewing war and revolution as part of one process); and, comparison (viewing Russia's war experience). As regards "continuum," there remains a vibrant debate over how "the Russian Revolution" should be understood. Is it a dynamic which is best limited to the year 1917, February to October? ${ }^{9}$ Or is it best placed in a broader arc: 1891-1924 (Orlando Figes), 1899-1924 (Richard Pipes), 1905-1921 (Peter Holquist), 1914-1922 (Aaron Retish), 1890-1928 (Steven Smith)? And as regards "comparison," it is notable, however, that -in contrast to studies of Russia in the First World War - there are far fewer works which seek to place Russia's revolutionary experience in comparative perspective. (Steven Smith is a rare exception.) $)^{10}$

Of course, the topic of violence had not been absent from studies of the Revolution. Roger Pethybridge in the early 1970s published two perceptive studies of the process and dynamics of the 1917 Revolution. His dissertation and first monograph

8. Ibid., 630 .

9. For a truly impressive synthetic presentation of the Russian Revolution as a 1917 event, see: Rex Wade, The Russian Revolution, 1917, second edition (New York: Cambridge University Press, 2005).

10. Steven Smith, Revolution and the People in Russia and China: A Comparative History (Cambridge: Cambridge University Press, 2008). Michael David-Fox is presently preparing an article on how the literature on comparative revolution could inform the historiography of the Russian field.

An earlier literature had examined the comparative morphology of revolutions, but not studied them as "intertwined histories" (histoire croisée): Crane Brinton, Anatomy of Revolution (New York: Vintage Books, 1965; original, 1938); Arno Mayer, The Furies: Violence and Terror in the French and Russian Revolutions (Princeton: Princeton University Press, 2000).

Some recent studies have examined the interconnection of revolutionary actors in the age of constitutional revolutions between 1905 and 1914 in the Russian Empire, Ottoman Empire, and Qajar Iran: Nader Sohrabi, "Historicizing Revolutions: Constitutional Revolutions in the Ottoman Empire, Iran, and Russia, 1905-1908," The American Journal of Sociology, 100, 6 (May 1995): 1383-1447; and Houri Berberian, "Connected Revolutions: Armenians and the Russian, Ottoman, and Iranian Revolutions in the Early Twentieth Century," in Francois Georgeon, ed., "L'ivresse de la liberté." La révolution de 1908 dans l'Empire ottoman (P.: Peeters, 2012). 
were devoted to the post-Stalin succession struggle, before shifting to the period of the Revolution and 1920s. On this period, Pethybridge relied largely on published documentary publications and memoirs. But he showed an impressive analytic insight. His The Spread of the Russian Revolution: Essays on 1917 (1972) foreshadowed later scholarly interests with its focus on the networks of communication and information in 1917 (the railways, the post and telegraph, supplies, the press, propaganda and political rumors), and the dynamic between Petrograd and the provinces. ${ }^{11}$ He followed this work with his 1974 The Social Prelude to Stalinism. ${ }^{12}$ Like the previous work, Social Prelude provided an insightful and penetrating analysis of the revolutionary years based on the memoirs and documentary publications. As the title suggests, Pethybridge was more interested in determining how the revolutionary era contributed to Stalinist rule than in the dynamics of the revolution itself. (The conclusion is titled "The Social Ingredients of Stalinism.") The focus is on how the experience of Revolution determined later events, rather than on the factors contributing to revolution and shaping its course. Pethybridge's very fine chapter "The Impact of War" is a compelling study of how violence shaped the Soviet system. But in its understanding of "war," the chapter focuses largely on the Russian Civil War following the 1914-1918 experience. (Sheila Fitzpatrick would develop this thesis in her focus on "the Civil War as formative experience." ${ }^{13}$ Focusing on the Soviet side of the Civil War, Pethybridge did not ask why the "social ingredients" did not produce an analogous outcome in the anti-Soviet regions. The discussion of brutalization and violence is by and large reduced to the Soviet side of the story. The Revolution, in this telling, is important for its later effects, rather than a dynamic or process in its own right.

Many historians who have confronted this question have answered it in terms of factors unique to Russia and the Soviet Union. One prominent interpretation focuses on Russian autocratic and patrimonial political traditions to explain the roots of Soviet interventionism. This view, exemplified by Richard Pipes in his Concise History, stresses the "unmistakable affinities" between tsarist patrimonialism and Soviet socialism, in particular their common systems of autocratic rule, extensive use of police powers, disregard for individual rights and private property, and state control of information. ${ }^{14}$ In the first volume of his two-volume study on the Russian Revolution, Pipes included three chapters specifically devoted to violence

11. Roger Pethybridge, The Spread of the Russian Revolution: Essays on 1917 (London: MacMillan-St. Martin's Press, 1972).

12. Roger Pethybridge, The Social Prelude to Stalinism (New York: St. Martin's Press, 1974).

13. Sheila Fitzpatrick, "The Civil War as Formative Experience," in Abbot Gleason, Peter Kenez, and Richard Stites, eds., Bolshevik Culture: Experiment and Order in the Russian Revolution (Bloomington, IN: Indiana University Press, 1985); Sheila Fitzpatrick, "The Legacy of the Civil War," in Diane Koenker, William Rosenberg, and Ronald Suny, eds., Party, State and Society in the Russian Civil War: Explorations in Social History (Bloomington, IN: Indiana University Press, 1990).

14. Richard Pipes, A Concise History of the Russian Revolution (New York: Vintage, 1996), 397-399. 
("War on the Village"; "Murder of the Imperial Family"; “The Red Terror"). Much like historians critical of the French Revolution dedicated much attention to the execution of Louis XVI, Pipes devotes one entire chapter to the murder of the Russian imperial family. In his treatment of the Red Terror, Pipes insists that it did not grow out of dynamic of mutual violence, but was solely a Bolshevik innovation. It was an "instrument of governance" (Russian Revolution, 790), and as such one cannot compare it the White Terror of anti-Bolshevik armies (Russian Revolution, 792; instructively, his treatment of White violence is found in the subsequent volume). In the first volume, Pipes foreshadowed an argument that he developed to a greater extent in Russia under the Bolshevik Regime: that Bolshevik violence was a necessary - if not entirely sufficient_-precondition for later Nazi violence (Russian Revolution, 791; Bolshevik Regime, ch. 5, esp. p. 261). ${ }^{15}$ For Pipes, the Bolsheviks conquered the Russian core by violence, and then used this platform to extend their rule (Bolshevik Regime, ch. 1, esp. p. 5, 9). Summing up the experience of revolution and civil war, Pipes insisted that Bolshevik practices were indigenous to Russia. It was all a tragedy "whose causes recede deep into the country's past" (Bolshevik Regime, 497). The authoritarian strands in Marxism came to the forefront in Russian conditions because they "fitted her patrimonial heritage" (Bolshevik Regime, 501). Finally: "Bolsheviks found models not in the writings of Marx, Engels, or other Western socialists, but in their own history" (Bolshevik Regime, 506). Pipes, I would suggest, is arguing for what Alfred Rieber has termed the heavy hand of "permanent conditions" in Russian history. Rieber has argued instead for thinking of "persistent factors" - and argument I find compelling. ${ }^{16}$

The school of ideology posits much different reasons for Russian revolutionary violence. Rather than features distinct to Russia or its revolutionary conjuncture of 1905-21, proponents of the ideological approach point either to the culture of the Russian revolutionary movement in general or Marxism as ideology in particular as the font for the violence in the revolutionary period. ${ }^{17}$ From this perspective, Russia's history from 1917 represented not a Russian Sonderweg, but a revolutionary or Marxist one.

As I have argued elsewhere:

In Russia - as in Italy and Germany - the war experience alone did not cause this shift; revolution was a necessary component. While the Bolsheviks employed violence more instrumentally and more consciously than their competitors, it had become an enduring feature of the post-1917 Russian political landscape.

15. Bizarrely, in making this argument, Pipes makes no reference to the Historikerstreit which has been ongoing since 1986. While referring to Ernst Nolte's earlier works, he does not discuss Nolte's 1986 article and the response it generated.

16. Alfred Rieber, "Persistent Factors in Russian Foreign Policy: An Interpretive Essay," in Hugh Ragsdale, ed., Imperial Russian Foreign Policy (Washington, DC: Wilson Center Press, 1993).

17. For discussions of the role of Marxism, see Stéphane Courteois, et al., eds., The Black Book of Communism: Crimes, Terror, Repression (Cambridge: Harvard University Press, 1999), esp. xviii, 262, 727, 735, 739, and Martin Malia, The Soviet Tragedy (New York: The Free Press, 1994). 
Bolshevik violence took place within this broader tectonic shift in Russianindeed European-political culture. If war and revolution were the crucial components, the experience of civil war provided the necessary catalyst. The practices of the governing and the governed crystallized in a concrete experience of war, revolution and civil war. Utopian dreams fused with an experience of want, fear, devastation, and brutalization. ${ }^{18}$ It was not simply Bolshevik measures that summoned forth violence from the Soviet state's opponents. To see Bolshevik measures as the cause of their opponents' violence is to miss this larger tectonic shift. ${ }^{19}$ Red political violence did not cause White violence, or vice versa. Rather, they were twin strands, inextricably intertwined, emerging out of the 1914-21 maelstrom of war, revolution, and civil wars. ${ }^{20}$

$$
* * *
$$

The reintroduction of the war as a framing device for the Russian Revolution is indeed very welcome. For many years, English-language historians of Russia examined the Russian Revolution as a discrete event, without tying it to the experience of the world war. In a parallel manner, historians of other European societies emphasized the significance of the First World War as the defining crisis of European history - but often overlooked the war's relationship to the postwar disorder, chaos, violence and revolution which followed through much of Europe. Each scholarly community, as it were, existed in its own historiographic bubble: European historians in their Great War bubble, and Russian historians in their 1917 bubble.

In the past two decades, there has been a greater tendency to examine the war and revolution as intertwined events. This shift has less to do with any specific revelations in the archives, than with the ability by scholars to range broadly across the now-open archival collections, in addition to a greater comparative engagement with the literature of other fields. ${ }^{21}$ And, with the centenary of the Great War's outbreak in 2014, there has been a recent boom in works on the Great War in general and Russia's role in it in particular. This outlook is represented most dramatically by the multi-volume Russia's Great War and Revolution project, published by Slavica Publishers. ${ }^{22}$ Readers should also note the excellent website "1914-1918 Online: International Encyclopedia of the First World War," which has

18. Donald Raleigh, Experiencing Russia’s Civil War, chap. 4 and conclusion. Memoirs and writings from this period portray this dynamic: Viktor Shklovsky, A Sentimental Journey: Memoirs, 1917-1922 (Ithaca, NY: Cornell University Press, 1984); Victor Serge, Memoirs of a Revolutionary, 1901-1941 (Oxford: Oxford University Press, 1980); and Isaac Babel, Red Cavalry, in Collected Stories (New York: Penguin, 1994).

19. E.g., Pipes, Russia under the Bolshevik Regime, 240-281.

20. Holquist, "Violent Russia, Deadly Marxism,” 650.

21. Peter Holquist, “A Tocquevillian 'Archival Revolution'? Archival Change in the Longue Durée,” Jahrbücher für Geschichte Osteuropas, 51, 1 (2003): 77-83.

22. For a description of the project, see: http://russiasgreatwar.org/index.php. 
very good coverage of Russia and Eastern Europe by a wide range of Anglophone and European scholars. ${ }^{23}$

Here I examine these developments through the lens of several key recent studies, with particular focus on the US and English scholarly world. I focus in particular upon Michael Reynolds's Shattering Empires; Willard Sunderland's The Baron's Cloak: A History of the Russia Empire in War and Revolution; and, Joshua Sanborn's Imperial Apocalypse. These works provide an opportunity to survey the broader literature on "the Revolution."

The tempo of publications on Russia in war and revolution together accelerated greatly with the 2014 centenary of the war's outbreak. (One wonders whether the 2017 centenary will see a spate of works stressing the significance of the Revolution as an event in its own right. And we are already seeing an emerging literature stressing not the impact of war and revolution, but the catalytic impact of post-war and post-revolutionary crises. ${ }^{24}$ Of course, the early Russian émigré literatureboth memoirs and historical studies - had identified this continuum, with some evoking the early seventeenth-century Time of Troubles. Many of the émigré military memoirs trace lives through the First World War into revolution and civil war. But the balance in the Anglophone historiography for much of the twentieth century presented the war and the revolution as discrete events. (For instance, the excellent two-volume study of the Revolution by William Henry Chamberlin, published in 1935; or Sheila Fitzpatrick's Russian Revolution. $)^{25}$

There were works as outliers, however, which pre-figured the later stress on how these two key processes - war and revolution - were intertwined. George Yaney's idiosyncratic 1982 The Urge to Mobilize traced the efforts to modernize the Russian countryside from 1861 to $1930 .{ }^{26}$ It is a book eccentric even in its form of citation: the book employs parenthetic citation favored by the social sciences, rather than footnotes. Perhaps because of the strangeness of the title, or its focus on agrarian modernization, the book had little effect-when it was published or today - on scholarship of Russia's World War or its Revolution, either among historians of the Russian Revolution or historians of the First World War more broadly.

23. http://www.1914-1918-online.net/. See, e.g., the fine entries by Reinhard Nachtigal and Lena Radauer on "Prisoners of War (Russia)"; Christopher Read, "Revolutions (Russian Empire)"; Peter Gatrell, "Organization of War Economies (Russian Empire)"; Chloé Drieu, "Turkestan"; or Susanne Schattenberg on "Brest-Litovsk, Treaty of."

24. Thomas Weber, Hitler's First War: Adolf Hitler, the Men of the List Regiment, and the First World War (New York: Oxford University Press, 2011), ch. 10; Jonathan Smele, The "Russian" Civil Wars: Ten Years that Shook the World, 1916-1926 (New York: Oxford University Press, 2016); Robert Gerwarth, The Vanquished: Why the First World War Failed to End (New York: Farrar, Straus, Giroux, 2016), with significant coverage of the Russian Civil War.

25. Chamberlin, The Russian Revolution, 1917-1921, 2 vols; Fitzpatrick, Russian Revolution, 1917-1932, with a short section in its "Setting" chapter on "The 1905 Revolution and its Aftermath; the First World War."

26. George Yaney, The Urge to Mobilize: Agrarian Reform in Russia, 1861-1930 (ChampaignUrbana, IL: University of Illinois Press, 1982). 
Hiding behind the enigmatic title, however, the book provides a probing analysis of the continuity in the modernizing "urge" across the 1917 boundary, with a special emphasis on the catalytic impact of the First World War. While detailing this "urge to mobilize," Yaney insisted that readers not think of his book "as a condemnation of modernity and its fantasies" (8). In his analysis, Yaney was an early advocate of the idea that the 1917 Revolutions in fact were preceded and prepared by the "revolution" of 1914-1915: "Those who consider 'revolution' to be a meaningful term might say that the Russian officer corps initiated the Russian Revolution" (419; similarly, 418, 420-421). The Russian state "was not to recover from the 'revolution' of 1914-1915 until 1921" (420). Beyond the army, Yaney argued that "for Russia's agricultural specialists agricultural improvement and World War I were much the same sort of operation. Both demanded peasant mobilization and justified the destruction of traditional peasant society. Both made the invasion of the peasant look like salvation" (446).

It has gone entirely unremarked that Yaney dedicated his idiosyncratic book "to the memory of Walter Rathenau, Tragic Prophet," and his chapter on World War I opens with an epigraph from Rathenau (p. 401; see also discussion of Rathenau's wartime measures as analogue for Russia's on p. 446-453). Indeed, Yaney followed Urge to Mobilize with a book dedicated to the management of the German war economy in World War I (The World of the Manager) - a book that also was largely ignored by historians of the Russian Empire and its revolution, including the recent scholarship on the Russian Empire in World War I. ${ }^{27}$ So-while largely ignored at the time and subsequently - Yaney's work prefigured the continuum of war and revolution, and also was an early advocate of placing Russia's war effort in comparative perspective with other combatant states.

Leopold Haimson's 1964-1965 article "Russian Social Stability" (cited above) had also prefigured the continuum between 1905 and 1917, between war and revolution. ${ }^{28}$ Many scholars portray Haimson in simplistic terms as simply a "pessimist" regarding the Russian empire's viability in 1914. In point of fact, his portrayal is more nuanced and dynamic. If there is one sentence in the article that encapsulates his argument, it would be that " 1914 is, if only approximately, a halfway station between 1905 and 1917." ${ }^{29}$ The article argues for process over the period from 1905 to 1917, not for a simple "either-or" proposition regarding the Russian empire's viability

27. George Yaney, The World of the Manager: Food Administration in Berlin during World War I (New York: Peter Lang, 1994).

28. "The Problem of Social Stability in Urban Russia, 1905-1917, Part One," Slavic Review, 23, 4 (1964): 619-642 and "Part Two," Slavic Review, 24, 1 (1965): 1-22; see also Haimson, "The Problem of Political and Social Stability in Urban Russia on the Eve of War and Revolution Revisited," Slavic Review, 59, 4 (2000): 848-875; and his final summation of his view, “The Workers' Movement after Lena: The Dynamics of Labor Unrest in the Wake of the Lena Goldfields Massacre (April 1912-July 1914)," in Leopold Haimson, Russia's Revolutionary Experience, 1905-1917: Two Essays, with an introduction by David M. McDonald (New York: Columbia University Press, 2005).

29. "The Problem of Social Stability in Urban Russia, 1905-1917 (Part Two)," 17. 
in $1914 .{ }^{30}$ Following this article, he continued to probe this continuum between "revolutionary situation" (1912-1914), war, and revolution. He published two separate volumes with Charles Tilly (in 1989) and with Giulio Sapelli (in 1992) on "strikes, wars, and revolutions in an international perspective." The goal of this major international project was, in Haimson's words, "to strive toward a purview of Europe's historical development in the late nineteenth and early twentieth century in which [...] Russia's historical experience [...] may be reintegrated [...] and find [its] proper place in a comparative perspective." ${ }^{31}$ This comparative project on strike movements throughout Europe on the eve and during the First World War anticipated the renewed interest in studying the First World War and especially of Russia's role in it.

At roughly the same time, Lars Lih published his monograph-developed independently from his Princeton dissertation in Political Science-on Bread and Authority in Russia, 1914-1921. ${ }^{32}$ Lih's work was an impressive study of the era of war, revolution and Bolshevik reconsolidation, told through the story of state food supply policy. Many subsequent works have rightly noted this study as a precursor to the later attention of the intertwining of war and revolution. His work had set itself the task of studying "not so much the food supply crisis itself but the disintegration of Russian society and the struggle to reconstitute it" (2). And he noted the crucial role of the Provisional Government over the course of 1917 as bridge to Soviet rule:

Since food-supply officials were no longer sanguine about either state consciousness or material incentives, the role of coercive incentives began to take on greater importance. The possibility of using force against grain producers had never been completely denied in 1917, although there had been hope in the beginning that the new solidarity and civic maturity would make it unnecessary

30. See also Leopold Haimson "Lenin, Martov, and the Issue of Power," in Haimson, Russia's Revolutionary Experience, esp. p. 197: "It is hardly possible to overemphasize the plasticity of the unfolding political situation throughout the period of Lenin's efforts to conquer and consolidate power. Nor can one overemphasize the flexibility of the political positions that both Lenin and Martov displayed in the course of the revolution, even while remaining true to the basic precepts about the character and role of political power in the dynamics of the revolutionary processes that each of them had drawn from their perceptions of the experience of the Russian Revolution of 1905."

31. Leopold H. Haimson and Charles Tilly, eds., Strikes, Wars, and Revolutions in an International Perspective: Strike Waves in the Late Nineteenth and Early Twentieth Centuries (New York: Cambridge University Press, 1989); Leopold H. Haimson and Guido Sapelli, Strikes, Social Conflict, and the First World War: An International Perspective (Milan: Fondazione Giangiacomo Feltrinelli, 1992), quotation from Haimson, "Preface" in Haimson and Sapelli, p. 4. See also his subsequent publications: Leopold Haimson and Eric Brian, "L'agitation ouvrière en Russie Impériale pendant la première guerre mondiale," Le Mouvement social, 169 (oct.-dec. 1994); Leopold Haimson, "Razvitie politicheskogo i sotsial'nogo krizisa v Rossii v period ot kanuna pervoi mirovoi voiny do fevral'skoi revoliutsii [The Development of the Political and Social Crisis in Russia from the Eve of the First World War to the February Revolution]," in Nikolai Nikolaevich Smirnov, with Ziva Galili, Reginald Zelnik, Boris Kolonitskii, S. Potolov, William Rosenberg, and Vladimir Iur'evich Cherniaev, eds., Rossiia i pervaia mirovaia voina (Materialy mezhdunarodnogo nauchnogo kollokviuma) [Russia and First World War], (SPb.: Dmitrii Bulanin, 1999).

32. Lars Lih, Bread and Authority in Russia, 1914-1921 (Berkeley, CA: University of California Press, 1990). 
[...] All in all, however, the attempts of the Provisional Government to use force were not impressive [...] The inability of the Provisional Government to use force effectively was due not only to inner inhibition but to lack of a reliable armed unit suitable for domestic purposes. (115)

In this, he anticipated my own work and the work of many other scholars.

By the late 1990s, a new wave of scholars had come to view the linkages between war and revolution. Orlando Figes published in 1996 a probing and wide-ranging overview of the Revolution, encompassing the years 1891-1924. The war years of course fell within his purview of analysis (ch. 7), with a shift then to a study of the revolutionary dynamic across 1917 (chs. 8-11). ${ }^{33}$ This work was followed soon after by Alessandro Stanziani's incisive examination of political economy across war and revolution. It - and several subsequent articles - traced continuities and ruptures across the 1917 divide..$^{34}$ (It is perhaps not coincidental that both Stanziani and I studied with Leopold Haimson.)

In 2002 I published my own book on Russia's "Continuum of Crisis, 1914-1921.” The following year I published an article in Kritika examining Russia's "epoch of violence." ${ }^{35}$ In an excellent, wide-ranging review essay on American studies of Russia in the First World War, Ol'ga Bol'shakova perceptively noted that my Kritika article in fact expanded the chronological boundaries which I had used in my earlier book. ${ }^{36}$ In Making War, Forging Revolution, I had written of a "continuum of crisis" spanning from 1914 to 1921. In the "Violent Russia" article, I had extended this continuum back before the start of the First World War, to the First Russian Revolution of $1905 .{ }^{37}$ I remain convinced that it is useful to begin a

33. Orlando Figes, A People's Tragedy: The Russian Revolutionary, 1891-1924 (NY: Viking, 1997 [UK original, 1996]).

34. Alessandro Stanziani, L'économie en révolution: Le cas russe, 1870-1930 (P.: Albin Michel, 1998); see also his many articles: "Spécialistes, bureaucrates et paysans. Les approvisionnements agricoles pendant la première guerre mondiale (1914-1917)," Cahiers du Monde russe, 36, 1-2 (1995): 71-94; "La burocrazia economica in Russia (1890-1930)," Clio, 31, 3 (1995): 379-414; "Le débat sur la rationalité économique en Russie, 1893-1930," Annales HSS, 1 (1996): 215-239; "La gestion des approvisionnements et la restauration de la gosudarstvennost'. Le Narkomprod, l'armée et les paysans," Cahiers du Monde russe, 38, 1-2 (1997): 83-116; "Les sources démographiques entre contrôle policier et utopies technocratiques. Le cas russe, 1870-1926," Cahiers du Monde russe, 38, 4 (1997): 457-488.

35. Peter Holquist, Making War, Forging Revolution: Russia's Continuum of Crisis, 1914-1921 (Cambridge, MA: Harvard University Press, 2002); "Violent Russia, Deadly Marxism: Russia in the Epoch of Violence," Kritika: Explorations in Russian and Eurasian History 4, 3 (Summer 2003): 627-652.

36. Ol'ga Bol'shakova, "Dolgoe vozvrashchenie v Evropu: Izuchenie Pervoi mirovoi voiny i amerikanskaia rusistika [A Long Return to Europe: The Study of the First World War and American Scholarship on Russia]," Rossiiskaia istoriia, 5 (2014): 26-35, here at p. 30.

37. For other work stressing the continuum of violence, see: Stephen Wheatcroft, "Towards Explaining the Changing Levels of Stalinist Repression in the 1930s: Mass Killings," in Stephen Wheatcroft, ed., Challenging Traditional Views of Russian History (Palgrave Macmillan, 2002), 112-45; Nicolas Werth, "Les déserteurs en Russie: Violence de guerre, violence révolutionnaire et violence paysanne (1916-1921)," in Stéphane Audoin-Rouzeau, Annette Becker, et al., eds., La violence de guerre, 1914-1945: Approches comparées des deux 
study of Russia's epoch of violence with the revolutionary violence of 1905-1907, since so much of the violence to follow saw the intertwining of what might call routine "military" violence with the violence of revolution and civil conflict and the violence of imperial rule and resistance to it.

Three recent English-language works in the Russian field have focused how the dynamics of the Russian Revolution catalytically interacted with dynamics of the First World War. Michael Reynolds' Shattering Empires: The Clash and Collapse of the Ottoman and Russian Empires, 1908-1918 appeared in $2011^{38}$. The most distinctive feature of Reynolds' work is its attention to trans-national and trans-regional linkages across the borders of the Russian and Ottoman empires. His account overturns much of the conventional wisdom about this period and this region. It is simultaneously an account of this region in a time of chaos, collapse, and re-ordering, and an analytic argument about how to understand empires and international relations. He insists that the key to the story is competition among states rather than the eruption of some elemental nationalism. Throughout the book, he demonstrates how these two imperial states operated within a competitive international order and how both sought to wield local movements and sub-state actors to their own benefit. While Reynolds examines these two empires as competing states, he devotes equal attention to the sub-state actors and local players who participated in this story and often frustrated the aspirations of empires. This account refreshingly reintroduces the Ottoman empire as an actor-and not simply a victim - in the clash of empires. His treatment of the continued importance of state and imperial concerns in an age of nationalism is an important methodological intervention. And his work demonstrates how productive it is to view Ottoman and Russian history as intertwined.

Willard Sunderland's The Baron's Cloak: A History of the Russian Empire in War and Revolution (Ithaca: Cornell University Press, 2014) also underscores the enduring imperial nature of Imperial Russian society and its citizens. He shows how this imperial aspect shaped the course of war and revolution. Sunderland's focus is on the life and times (a microhistory, rather than biography) of Baron Roman Fedorovich Ungern-Sternberg, and the book aims to treat him as a "guide, using his life to open up the empire's sprawling patchwork" (xi) - a study of the Russian empire through one exemplary (if truly shocking) life. By following one individual life - that of the fascinating if ominous Baron Roman Fedorovich von

conflits mondiaux (P.: Éditions complexe, 2002); Nicolas Werth, "La société russe en guerre: La guerre de huit ans (1914-1922)" in Bruno Cabanes and Édouard Husson, eds., Les sociétés en guerre, 1911-1946 (P.: Armand Colin, 2003), 75-94; Dietrich Beyrau, "Der Erste Weltkrieg als Bewährungsprobe. Bolschewistische Lernprozesse aus dem 'imperialistischen' Krieg," Journal of Modern European History 1, 1 (2003): 96-124; Joshua Sanborn, "Unsettling the Russian Empire: Violent Migrations and Social Disaster in Russia during World War One," Journal of Modern History 77, 2 (June 2005): 290-324; Peter Holquist, "Forms of Violence during the Russian Occupation of Ottoman Territory and in Northern Persia (Urmia and Astrabad), October 1914-December 1917," in Eric Weitz and Omer Bartov, eds., Shatterzone of Empires: Coexistence and Violence in the German, Habsburg, Russian and Ottoman Borderlands (Bloomington, IN: Indiana University Press, 2013), 334-361.

38. Michael Reynolds, Shattering Empires: The Clash and Collapse of the Ottoman and Russian Empires, 1908-1918 (Princeton, NJ: Princeton University Press, 2011). 
Ungern-Sternberg - Sunderland elucidates how apocalyptic violence became an attractive mode of being for Ungern-Shternberg. Sunderland suggests that we need to understand Ungern-Sternberg as a type,rather than simply as a pathological individual. He shows how imperial Russian society produced Ungern-Shternberg as an imperial cosmopolitan, albeit one of a highly toxic sort. It is life in several acts: Graz, Austria; the Baltic Provinces; St. Petersburg; Manchuria; Russia's Far East; the killing fields of the First World War in Prussia, Galicia, Persia; and the crescendo in Revolution and Civil War, with the Baron's dramatic end in Mongolia and Siberia.

Sunderland argues that the frame for the Baron's life was the Russian Empire. But he insists equally that this imperial life became entwined in the struggles over Revolution, leading to his committed engagement in the Civil War. In his words, "The Great War did not cause the revolution - given all the tensions and complexities of the empire, a revolution may well have occurred in Russia anyway. But the war guaranteed that whatever revolution did occur would be especially violent" (p. 135). As Sunderland notes, the Civil War was more destructive and murderous than even the "Great" War: there were two million dead due to the First World War in the Russian Empire, mainly military deaths; in Russia's civil wars which followed, fourteen to fifteen million people-mainly civilians - died (p. 159).

Joshua Sanborn's impressive Imperial Apocalypse also views the years of war and revolution through the prism of empire.$^{39}$ His book makes the important point that the collapse of empire was an important process in its own right, one proceeding alongside the course of war. He began the book with the goal of recovering the experience of everyday life in the warzone. But in the course of researching and writing the book, he became convinced that the story he was seeing was one of the "decolonization" of the Russian empire (vii). The book remains indebted to its original inspiration, in that it often tells its story through vignettes and moments of individual lives. This view of the experience of war, collapse and revolution through the experience of individual lives is one of the book's signal strengths.

Imperial Apocalypse makes two fundamental arguments. First, it insists that the period of war, revolution and civil war is best understood as a process of "decolonization." The book traces the "causal chain" of "military violence, state failure, social collapse, and end of empire" (vii). In a statement of purpose, the book argues:

This book proceeds from the premise that the collapse of empire in Europe was indeed a significant historical event. This process took place over the whole duration of the war, not simply during the peace conferences that ended it. The Great War was a war of European decolonization [...] the fact of decolonization in Eastern and Southeastern Europe was one of the most tangible and significant outcomes of the conflict. (3)

39. Imperial Apocalypse: The Great War and the Destruction of the Russian Empire(New York: Oxford University Press, 2014). See also, along these lines, Buldakov, Krasnaia smuta, and V.P. Buldakkov and T.G. Leont'eva, Voina, porodivshaia Revoliutsiiu: Rossiia, 1914-1917 gg. [The War which Gave Birth to Revolution: Russia, 1914-1917] (M.: Novyi khronograf, 2015). 
There is much to agree with here. As noted above, Sanborn makes a major point in insisting that previous scholarship, in focusing on either war or revolution, has overlooked "the collapse of empire" as a key dynamic over these years. (Sanborn's work thus provides a productive frame for thinking about a number of works, which have appeared on continuum of war and revolution in Central Asia across the revolutionary divide. ${ }^{40}$ And he is surely right (as quoted above on p. 3) that this "collapse of empires" took place "over the whole duration of the war, not simply during the peace conferences that ended it." 41

Sanborn's analysis focuses on socio-economic disintegration and population displacement within Russia as the key processes throughout the war, which led to "imperial collapse." (To this set of processes, I would add the overall war aims dynamic and the revolutionary agendas pursued by imperial Germany in occupied territories. $)^{42}$ As I noted in my review of that book, however, I am not entirely convinced that "collapse of empires" - an important theme for this period-is necessarily the same process as "decolonization," an analytic category that the book does not define. ${ }^{43}$

Imperial Apocalypse's other major argument is that the Revolution was not so much a product of revolutionary processes within Russian imperial society as the Revolution was the culmination of developments during the war. The Revolution as project and process is largely absent. Rather, "revolution" was the sum of a concatenation of processes unleashed by the war: "The Russian Revolution as a whole was a product of the war and was decisively influenced by soldiers at every key stage" (235). The years 1914-1917 saw the imperial structure fail and collapse utterly: "the engine of this transformation was combat against the Central Powers" (249).

40. Adeeb Khalid, The Politics of Muslim Cultural Reform: Jadidism in Central Asia (Berkeley, CA: California University Press, 1998) and Making Uzbekistan: Nation, Empire, and Revolution in the Early USSR (Ithaca, NY: Cornell University Press, 2015); Daniel Brower, Turkestan and the Fate of the Russian Empire (New York; Routledge, 2003); Marco Buttino, La rivoluzione capovolta: L'Asia centrale tra il crollo dell'impero zarista e la formazione dell'Urss (Napoli, 2003; Russian translation, 2007) and "Central Asia (1916-1920): A Kaleidoscope of Local Revolutions and the Building of the Bolshevik Order" in Eric Lohr, Vera Tolz, Alexander Semyonov, and M. von Hagen, eds., The Empire and Nationalism at War, (Bloomington, IN: Slavica, 2013); and Joern Happel, Nomadische Lebenswelten und zarische Politik: Der Aufstand in Zentralasien 1916 (Stuttgart: Franz Steiner Verlag, 2010).

41. See also Lohr, Tolz, Semyonov, and von Hagen, eds., The Empire and Nationalism at War.

42. On the overall war aims dynamic and general processes, see Aviel Roshwald, Ethnic Nationalism and the Fall of Empires: Central Europe, Russia and the Middle East, 1914-1923 (London: Routledege, 2001); on occupation as a revolutionary experience, see Mark Von Hagen, War in a European Borderland: Occupations and Occupation Plans in Galicia and Ukraine, 1914-1918 (University of Washington Press, 2007).

For the revolutionary developments of German occupation policy in the East, see Vejas Liulevicius, War Land and the Eastern Front (New York: Cambridge University Press, 2000); and, for a compelling earlier sketch of this argument, Geoff Eley, "Remapping the Nation: War, Revolutionary Upheaval, and State Formation in Eastern Europe, 1914-1923," in Howard Aster and Peter J. Potichnyj, eds., Ukrainian-Jewish Relations in Historical Perspective (Edmonton: Canadian Institute of Ukrainian Studies, 1990), 205-222.

43. Peter Holquist, "Featured Review of Joshua Sanborn, Imperial Apocalypse: The Great War and the Destruction of the Russian Empire," Slavic Review, 73, 3 (Fall 2015): 600-603. 
The book makes this argument that war alone caused revolution by claiming that the Russian imperial state and society had stabilized after 1905 and were becoming stronger and more robust. Imperial Apocalypse avers that the Russian state began the war as fully-functioning organization of power, and it was the war that reversed the prewar trend of "state-strengthening." (248; also 247)..$^{44}$ When discussing unrest, both for 1905 and for 1917, the book discusses the peripheries but has little to say about unrest in the European Center, as regards the relationship between prewar dynamics of labor unrest and wartime strike waves or, even more dramatically, as regards agrarian unrest in European Russia in 1905 and again in 1917. Indeed, a general tendency of studies linking war and revolution has been to overlook the dynamics of rural unrest in European Russia, arguably one of the major drivers of the 1917 revolutionary dynamic. Contrast this approach with some of the more interesting recent discussions of the unfolding of the 1917 Revolution, by Aaron Retish - note especially his chronology of 1914-1921 - and Sarah Badcock. ${ }^{45}$

The book's neglect of revolutionary developments before 1917 is equally true for labor unrest. In discussing the period on the immediate eve of the war, Imperial Apocalypse describes the forest fires raging around St. Petersburg in June 1914 (21) but chooses entirely to ignore the July 1914 general strike in St. Petersburg, the focus of Leopold Haimson's examination of the viability of Imperial Russia on the eve of the war and-Haimson argued - the crucial hinge between 1905 and $1917 .{ }^{46}$ Or again, in treating the labor unrest in 1915 in Kostroma, Sanborn presents it as a case of "the front coming home" (96-98) rather than as the re-activization of earlier, prewar labor dynamics, as was argued by an earlier literature. ${ }^{47}$

$* * *$

The turn in recent literature to placing the revolution within the broader context of the First World War and situating Russia's collapse within the framework of Empire are both very welcome developments. These two approaches allow, among other things, for new arenas for comparative discussion about the causes, course, and consequences

44. For other works arguing for the vitality of the socio-political order in Imperial Russia on the eve of the war, see Michael Melancon, The Lena Goldfields Massacre and the Crisis of the Late Tsarist State (College Station: Texas A\&M University Press, 2006) and Wayne Dowler, Russia in 1913 (DeKalb, IL: Northern Illinois University Press, 2010).

45. Aaron Retish, Russia's Peasants in Revolution and Civil War: Citizenship, Identity, and the Creation of the Soviet State, 1914-1922 (New York: Cambridge University Press, 2008); Sarah Badcock, Politics and the People in Revolutionary Russia: A Provincial history (New York: Cambridge: Cambridge University Press, 2007). See the earlier path-breaking work of Orlando Figes, Peasant Russia, Civil War: The Volga Countryside in Revolution, 1917-1921 (Oxford, UK: Clarendon Press, 1989).

46. Haimson, "The Problem of Social Stability in Urban Russia, 1905-1917."

47. Leopold Haimson and Eric Brian, "Labor Unrest in Imperial Russia during the First World War: A Quantitative Analysis and Interpretation," and David Mandel, "The Ivanovo-Kineshma Workers in War and Revolution," both in Haimson and Sapelli, eds., Strikes, Social Conflict and the First World War. See also Gleb Albert, "Labour Movements, Trade Unions and Strikes (Russian Empire) in: 1914-1918-online. International Encyclopedia of the First World War (accessed Feb. 22, 2017). 
of the Russian Revolution. At the same time, I worry that this new focus has led us away from some of the key observations made in the earlier literature. I wish in this final section to make this point by engaging and embroidering upon several arguments made in Steven Smith's recent Russia in Revolution: An Empire in Crisis, 1890-1928. ${ }^{48}$

As a scholar who argued for situating the Revolution within a broader continuum of crisis, one in which the war is a crucial context, I welcome the attention to interconnection of war and revolution. But in doing so, I would also insist that we not lose sight of the Revolution as a dynamic in its own right, and not simply an epiphenomenon of wartime processes. In this, I would cite Baron Boris Nol'de, a participant and observer of war, revolution and the initial stages of civil war:

The events of the [Russian] revolution present us with a twofold historical aspect. First, the crisis was one of the numerous European revolutions that emerged out of the Great War. [...] But it would be wrong to assume that the war, with all its enormous difficulties, could explain, in and of itself, the Russian catastrophe [...] At the same time, and to an even greater degree, the Russian Revolution was the product of a certain domestic condition. [...] In short, the two aspects of this concrete historical situation are but two different sides of one and the same sociological reality. ${ }^{49}$

The focus on war and empire elucidate certain features of the revolutionary process. But, as Nol'de suggests, these two factors (war and empire) fail to explain other key dynamics - "the certain domestic conditions" - which accounted for how the Revolution unfolded as it did.

The Russian Revolution produced the triumph of the Bolshevik Party and the Soviet state. While this triumph of the Bolsheviks was not inevitable, one of the striking features of 1917-one of the truly distinctive features of Russia's Revolution - was the near-total predominance of the socialist option in electoral politics from the spring and summer going forward. To be sure, there remained the threat of military coup (as attempted by Lavr Kornilov). But from summer 1917 forward the menu of electoral options narrowed considerably, to essentially a spectrum from the moderate left to the radical left. After February, the most viable party on the political right was Russia's traditional party of liberalism, the Constitutional-Democrats. ${ }^{50}$ Consider this situation for a moment, compared to other societies emerging from the First World War: Hungary, Finland, Germany, the Turkish Republic. The rightist option was largely

48. Steven Smith, Russia in Revolution: An Empire in Crisis, 1890-1928 (New York, Oxford University Press, 2017). While Smith's chronology is expansive and includes the war years, he insists "The collapse of the tsarist regime in Febuary 1917 was ultimately rooted in a systemic crisis brought about by social and economic modernization, a crisis that was massively exacerbated by the First World War" (9; see also 79, 134).

49. Boris Nolde (Nol’de), L'Ancien Régime et la Révolution russes (P.: Librarie Armand Colin, 1948), 102-103. Nol'de's title consciously evoked Alexis de Tocqueville's study of the French Revolution, L'Ancien Régime et la Révolution (1856).

50. See the superb and still very relevant William Rosenberg, Liberals in the Russian Revolution: The Constitutional Democratic Party, 1917-1921 (Princeton, NJ: Princeton University Press, 1974). 
absent as an electoral force, throughout the cities and the countryside. As Smith observes, over 85 percent of the vote in the Constituent Assembly elections went to parties describing themselves in some way as socialist. ${ }^{51}$ There can be little doubt that this electoral terrain was a product of Russia's prewar order, more than it was due to war or empire as independent factors.

The triumph of the Soviet state in the Civil War was dictated in no small part by its ability to hold the heartland of European Russia throughout this period, while the anti-Soviet forces held the periphery. This geographic disposition of forces was not simply happenstance..$^{52}$ Here the question of earlier dynamics of urban and rural unrest is helpful. If one adapts an expansive time frame, one stretching back before 1914, such as is found in the works of Orlando Figes and Steven Smith, one can map the unrest of 1902, 1905-1907, and 1912-1914 onto the later geography of revolution and civil war. And it is a telling juxtaposition. While imperial Russia may have been becoming more vital following 1907, we would do well to remember that no other major European society had suffered a collapse so close to the war such as that of 1905-1907 in Russia. And these fissures surely shaped the course of events after February 1917. Thus when Pipes writes "Their geographic position gave the Reds not only strategic advantages, but also incalculable material benefits, " ${ }^{3}$ we might ask why the Reds came to occupy that crucial geographic position, and managed to hold it throughout the Civil War. It was the Bolsheviks' ability to hold the European core and then use it as a platform for its impressive project of territorial Reconquista that secured the Revolution in its final, Soviet form.

So I want to conclude by insisting that-yes-there was such a thing as the Russian Revolution. The dynamics of the First World War and tensions of empire powerfully shaped the course of 1917 . Yet the Revolution also grew out of revolutionary dynamic in its own right. ${ }^{54}$ This dynamic helps explain both the nearubiquity of socialism on Russia's political scene as well as the dynamics of Bolshevik victory, rooted in holding Russia's core rather than its periphery.

\section{University of Pennyslvania}

holquist@sas.upenn.edu

51. Smith, Russia in Revolution, 13, 137,337. For an earlier study coming to analogous conclusions, see Oliver Radkey, Russia Goes to the Polls: The Elections to the All-Russian Constituent Assembly, 1917, revised edition. (Ithaca, NY: Cornell University Press, 1990; original, 1950); see also L.G. Protasov, Vserossiiskoe uchreditel'noe sobranie: Istoriia rozhdeniia i gibeli [The All-Russian Constituent Assembly: A History of its Birth and Death] (M.: ROSSPEN, 1997).

52. Pipes speaks simply of the Reds" "advantages of their geopolitical situation," one over which they had no control-and avers that the Bolsheviks had no real support other than the party apparatus itself in this space (Pipes, Bolshevik Regime, 9, 135-138).

53. Pipes, Bolshevik Regime, 11. Pipes ascribes Bolshevik control of this space simply to the fact that they had "conquered" it (13): but why did they succeed at this, when others failed?

54. Smith, Russia in Revolution, 9, 79, 134. 